\title{
Ana Petrov
}

\section{Listening to Music in 'Holy' Space: The Role of 19th-Century Public Concert in the Construction of Kunstreligion}

\section{Poslušanje glasbe v »posvečenem« prostoru: Vloga javnega koncerta pri ustvarjanju Kunstreligion v 19. stoletju}

Prejeto: 26. december 2012

Sprejeto: 27. marec 2013

Ključne besede: koncert, koncertna dvorana, kontemplativno poslušanje, Kunstreligion, estetika glasbe 19. stoletja

IZVLEČEK

Prispevek se ukvarja z institucijo javnega koncerta v 19. stoletju in njegovo vlogo pri stvaritvi koncepta Kunstreligion. Opazujem ta koncept, prikazujem, kako je nastal, ter opozarjam na vzvode, ki so koncert povzdignili v nadomestilo za cerkveno obredje.
Received: 26th December 2012

Accepted: 27th March 2013

Keywords: concert, concert hall, contemplative listening, Kunstreligion, nineteenth-century music aesthetic

\section{Abstract}

This paper deals with the 19th-century institution of public concert and its role in the construction of the concept of Kunstreligion. I elaborate on the concept showing how it was produced, by pointing out to the mechanisms that made the concert an alternative to the church service.

\section{Introduction}

This paper deals with the institution of concert and focuses on the phenomenon of Kunstreligion that was made due to this institution in the first half of the 19th century (when the concert was being significantly altered). ${ }^{1}$ Having in mind that the concert life

1 The concert world in most European centers (Vienna, London, Paris) underwent an upheaval during the first half of the 19th century because of the drastic expansion of its commercial bases. Along with the social changes of the time, the invention of lithography, the improvements instruments, the building of larger halls and opera houses and the development of marketing and sales techniques led to an outpouring of music designed to attract a much larger public than before. During the second half of the 19th century the concert public expanded greatly within the middle and working classes. The main impetus to increased concert-going was the near-universality of the piano in middle- and upper-class homes, which by this time was spreading to less affluent groups. While the rage for virtuosos closely tied to domestic music-making died down in the 1850s, the continuing growth of musical education stimulated musicians to establish concerts for a much wider public (Weber 2001). 
also exhibited intense social changes that were happening among social strata which were to have influence on the way the members of a certain stratum spent their free time, I draw on Pierre Bourdieu's concept of distinction in order to construe concert as a form of cultural activity that was in service of creating and confirming the new status of bourgeoisie and its cultural ethos (Bourdieu 1979). Since the concerts were held in different places (concert halls, cafés, restaurants, parks, salons or ballrooms) they offered diverse entertainments. Although considering the differences between the concerts, I will here focus on the ways the concept of Kunstreligion was being created and at which target social group and the life style it was aimed. ${ }^{2}$ In the case of $19^{\text {th }}$-century concerts, the distinction was being constructed mostly among the members of a class that included attending (or inability to attend) a certain type of concert into their life style. Thus, concert was 'a kind of museum' for developing and cultivating the public's taste (Gramit 2002,154). I will here focus on the role of a specific kind of concert that did help creating and propagating certain taste, life style, as well as a specific behavior. ${ }^{3}$

According to William Weber, institutional concerts ('high status' or 'prestige classical music' concerts) were the channels for giving an official visible confirmation for the new elite (Weber 2004, 61). Those were the concerts organized by established, well organized institutions (such as philharmonic societies) and they were reserved for the public who could afford tickets, usually through subscription for the whole year in advance. ${ }^{4}$ Since the concerts were mostly closed events, mixing of the classes was not easy or even possible. These concerts have usually been labeled as mechanisms for constructing music ideology that formed the paradigm of serious music, having as the consequence the propagation of 'higher' taste of the audience that was supposed to understand, love and appreciate 'serious', 'classical' or 'art' music (Gramit 2002, Weber 2004). ${ }^{5}$ Furthermore, it is certain that a specific behavior style was being created in these concerts, thus forming rather unique micro-social situations. Namely, there was a process that regulated behavior and actions during the concerts, now commonly referred to as the 'cultivation project'.

Life style is here understood as a system of habits that entails certain behavior patterns and is intertwined with the idea of taste that helps creating a sense of distinction (Čejni 2003, 13).

3 For a detailed analysis of the concert as a social event see: Petrov 2011.

4 The most important new institution established throughout Europe and America in the 19th century was the professional orchestra. Orchestras evolved out of pre-existing music societies or court concert groups, or from new organizations directed by the musicians themselves. Besides the Gewandhaus Orchestra, the most important ensembles developed in national capitals, usually founded and governed by musicians: the Philharmonic Society of London (1813), the Société des Concerts du Conservatoire in Paris (1828), the Gesellschaft der Musikfreunde in Vienna (1842) and the Berlin PO (1882). In the USA, the major orchestras, notably the Philharmonic Symphony Society of New York (1842) and the Boston Symphony Orchestra (1881), were founded and directed chiefly by wealthy patrons (Weber 2001).

5 However, the concert was not the only channel for producing the new ideology. Tia DeNora argues that the initial phase of the emergence of serious music ideology in late 18th- and early 19th-century Vienna happened due to the elite receptivity to the new ideology as it occurred against a backdrop of change in the organizational basis of music sponsorship. Namely, the decline of the private house ensembles (Hauskapellen) resulted in a social broadening of music patronage and thereby tended to erode the traditional institutional means for aristocratic authority in musical affairs. The exclusive function that the qualitatively different ideology of 'serious' music could provide reaffirmed traditional cultural boundaries through ideological rather than institutional means and enabled Vienna's old aristocrats to emerge after 1800 in the context of the salon music performances (DeNora 1991). 


\section{Cultivation project}

The ideal of 'high' musical culture was being constructed at the end of the $18^{\text {th }}$ and the beginning of the $19^{\text {th }}$ century. The changes in the social status of musicians, as well as the organizers of musical life are considered to be crucial factors that helped production of the concept of 'serious' music (Gramit 2002, 20). The process of creating the concept of serious music - together with its opposite popular music, music for fun - was intertwined with the complex project of cultivating audience through music. Serious music concert was one of the salient examples of the ways the project was conducted. The project was constituted in the first half of the $19^{\text {th }}$ century, having been based on the enlightenment ideas of cultivation that construed music as an adequate means for educating entire population. It was assumed that music was a good means for building a good communicative and sociable person. In accordance with that, the concert musical culture was understood as something divergent from fun for its own sake, but rather as a way of useful and well organized spent time (Gramit 2002, 17). The concept of 'good' taste was also a part of the project, since it was necessary to educate people to make difference between 'good' and 'bad' music and cultural ('art') entertainment from having fun with no 'higher' purpose. The taste was certainly one of the important social values that were being produced due to the institution of concert. ${ }^{6}$ The 'serious' music concert was part of the project, being an ideal for well-off members of society. The concert was thus reserved for 'cultivated' classes (Gramit 2002, 18) and as a cite of 'cooperative interaction of all classes' (Gramit 2002, 149), serving as an exemplar of a well organized cultural institution with precisely and strictly defined social relations and rules of behavior, and bringing to the formation of the 'higher' musical culture elitism (Ellis 2002, 356). ${ }^{7}$

The organization of social relation in the concerts was of crucial importance for constitution of this type of concert as an ideological fundament of high music culture. Due to the concert, different kinds of accepted behavior patterns were formed, thus being a basis for interpersonal relations during the event. I will firstly address the issue of proper way of listening to music that certainly represents one of the most important behavior patterns, and then I will deal with the space that was changed due to the concerts. I will thus show how the concert was an indicator of formation of specific social space as a reality that was constructed through this institution with help of specific cultural patterns. One of the highly relevant means for cultivation project to succeed in concerts was the idea of Kunstreligion, the idea that music should be valued as Godlike entity and the concert space should be thus equivalent to the church. Finally, the gist of the behavior patterns was a request: behave as if you were in the church.

6 The values that were produced could be seen in judgments of the music that was performed, in creation of genre hierarchy in the repertoire, the importance that was given to professional musicians, and in the division of the audience on 'connoisseurs' and 'laypersons' and the division of art on 'high' and 'low'.

7 The serious music concept was incorporated into the cultivation project as an ideal appealing to well off members of bourgeoisie, the concert thus being reserved for those cultivated classes. It is highly important, as shown in a considerable number of studies, to construe concert as a social event, since social relations made in concerts were more, according to music sociologists, more important for this institution than the performative aspect of it, which is supported by the reviews of the concerts that were more often than not dedicated to the social space of the event (it was reported who was present, what was discussed and similar, Gramit 2002, 143). 


\section{Contemplative Listening}

What separated the concert institution from its inception (in the $17^{\text {th }}$ century) from other music events was the formation of the act of listening. Concert has always been an institution in which music was in the center of social attention. In all other contexts it was a concomitant activity, so that actual listening as an autonomous activity did not exist. The act of concentrated, focused listening was not a usual scene to be seen in concerts for a long time. ${ }^{8}$ Moreover, listening was not the most important part of many concerts and it was not changed quickly and drastically. On the contrary, on numerous occasions, music was inferior to other activities, like socializing during dancing evening or popular music concerts in general, or in opera (Johnson 1995). It was not rare that concert performing entailed inferior role of music. Divergent concerts had divergent strategies of listening. However, a salient change in the act of listening did happen exactly at the serious music concerts. The behavior patterns, holding and socializing in a concert hall were being formed during the $19^{\text {th }}$ century and has been valid ever since. By the end of the century, a whole new discourse on specific behavior, posture, acting, listening and communicating was constructed. The idea was promulgated in philosophical and literary discourses, as well as in the press, in reviews where it was in fact confirmed that the actual change in behavior was happening (Morrow 1997).

The gist of the Kunstreligion discourse was the premise that one should behave in a concert hall as if being in a church. In other words, it was proclaimed that listening to the music in the serious music concerts was a sort of spiritual experience (Kramer 2005, 95). Philosophical and literary discourse in the $19^{\text {th }}$ century is fulfilled with detailed descriptions of the expected conduct of the listeners - it was expected from a concert goer to be concentrated on the music with the same attention and respect as in church and during the concert it was supposed that similar contemplation is to be happening as during a church ritual. This act of contemplative listening is also known - in the aesthetical and musicological discourses - as the concept of aesthetic contemplation. Moreover, this kind of spiritual listening was not reserved solely for sacred music, nor for the church as an institution. On the contrary, it was especially expected and usually seen in public concerts with classic canon repertoire, organized in concert halls. It became common, preferred and, even more, requested that a person should behave in a specific strictly defined way. The recommendations for 'proper' behavior included: holding still, being quiet and respectful, keeping your body almost motionless, contemplating and keeping your mind concentrated on music, reduce talking to the minimum. These concerts were thus reserved for the audience that was considered 'cultivated' enough to act 'religiously' while listening to music (Kramer 2005, 117).

The umbrella term that entailed the mentioned behavior was 'spiritual contemplation' which final instance was not connected to the church, and the origin was to be found in the religious discourses and practices at the beginning of the $19^{\text {th }}$ century. Within spiritual

8 Nevertheless, serious listening had existed before the rise of formal concerts, most prominently in churches and in courts. While music is the focal point of a concert, that does not necessarily mean that an audience obeyed an etiquette of complete silence and stillness. Informal social practices continued in some concerts, for example in tavern performances in the 18th century, at 'promenade' concerts in the 1830 s and 40 s and more recently, and at band concerts during the 20 th century. A strict social etiquette became the norm in concert life around the middle of the 19th century, linked closely to the new aesthetic of the time and to certain types of concerts (Weber 2001). 
contemplation there were two opposite concepts - of activity and passivity, beautiful and sublime, sensory and spiritually, all of the mentioned themes fitting in the broader concepts of Andacht and Anschauung. The former concept was connected to the active aspect of contemplation that can be shortly described as 'active thinking on something', while the latter, contrary to that, referred to intuition and perception (Kramer 2005, 122). Although originally referring to the expectations from the believers in church, those constructions were started to be applied and to be propagated in the $19^{\text {th }}$ century discourses to the listening to music in church, as well as listening to instrumental music. It was claimed and also commented in concert reviews that a listener in a concert should and does indeed listen carefully and pay attention with the same Andacht as in church. Acting in accordance with the postulates of aesthetic contemplation existed during performances in church or in concerts in concert halls. It was not usual or expected behavior for the audience during opera performance, for instance. Thus, listening in concert was presented as an active listening, activity of the whole body, which was the very reason why the body should have been still, motionless, almost paralyzed - it was because of the concentration and focus solely on music itself.

On the other hand, music was also being connected with Anschauung concept, especially when sacred music pieces were performed since they were aimed at religious meditation that is spontaneous, intuitive communication with God. Thus, active and passive listening could co-exist, since mental focus and concentration were concomitants of stiff body and fixed gaze did not exclude a possibility for intuitive insight and enjoyment in music. Passivity thus referred to very behavior, way of acting and talking, while activity referred to 'thoughts and fantasies' that were expected to be present in the minds of listeners during listening to music in a concert. This state of mind and this kind of behavior should have resulted in a unique music experience that was supposed to be equivalent to religious meditation, thus getting to the culmination of the act of listening being an insight into beautiful, sublime and spiritual. Moreover, this behavior also meant that a person knows how to behave, that one has proper manners, that he or she is polite, educated, well-rounded, well-mannered, well behaved in general, which were desirable and necessary qualities for incorporation and acceptance in social life (Johnson 1995, 228-236).

Having in mind the mentioned, it is also relevant to point to the importance of silence in concert space. Being quiet was desirable, appreciated and necessary quality that was expected from a well mannered concert goer. No less important was also the very space, the concert venue, in which this kind of music performance was taking place. Certain norms related to behavior were easier to get visible in adequate places, specifically designed for the purpose. It was necessary to construct not only the behavior patterns but also the very space in which the patterns were going to be presented as requirement that had to be met, although the space was in fact formed mostly by the very behavior in it. Thus, the concept of art as religion and listening to music as a religious contemplation had impact on the very architectural solutions of the concert spaces. Just as the conduct based on the premise 'act as if you were in a church' was promulgated in contemporary discourses, the very act of listening and the act of being silent gradually became unavoidable requests for spending time while in a concert, and so did the holy space in which the whole performance of this described normative behavior was taking place. 


\section{Holy place: concert hall}

Concert hall was a place of gathering of concert goers, music lovers (Liebhaber), enabling them, as Antje Pieper puts it, 'a visual confirmation of the new status of the middleclass and its cultural ethos' (Pieper 2008, 59). ${ }^{9}$ Forming strictly defined rules of behavior was easier due to the fact that a specific place for such a behavior was being made. The image of the place was also strictly defined and was in accordance with behavior pattern, thus helping them to get firmer and more visible. The hall made the cultural conventions public, while group activities practiced there were meant to give the hall its own recognition in the public, since these activities were a platform for building a group cultural identity (Pieper 2008, 97). Furthermore, especially relevant is the process of sacralization of the space in which the concerts were organized, which, joined with the cult of contemplative listening and the ideal of silence, brought to the fundamental transformations of the concert as a social bourgeois institution. Namely, unlike aristocracy to which culture was a way of having fun and being amused, to middle class culture was supposed to be spiritual upbringing. In accord with that ideal, the space dedicated solely to public concerts performances was being built - it was expected from those concert places to highlight the role of music as a spiritual experience and a means for individual development (Pieper 2008, 101).

Sacralization of the concert started around 1800, being manifested in the attitude both of the audience and the critique that concert was similar to divine service (Gottesdienst) in church (Kramer 2005, 134, Weber 2001). Namely, concert was construed as an opportunity in which both time and space art would unite in order to create an entity similar to ancient Greek drama for which it was believed that it was the perfect unity of all arts. ${ }^{10}$ One of the most obvious indicators of this $19^{\text {th }}$ century tendency was the design of the concert halls having in mind that they were modeled after churches and temples. Since concerts were becoming increasingly more popular starting from the beginning of the $19^{\text {th }}$ century, there was a need for new concert spaces. Religious style thus became rather popular and expected at the time, especially after new concert halls were built, for instance, in Berlin and Munich. Religious motives are here also noticeable both in architectural neo-classical solutions (thus leading concert hall to an image similar to ancient temples, often having basilica like solutions, for instance) and in interior design (which

9 During the early 18 th century concerts were performed in spaces designed to accommodate a variety of activities, chiefly meetings and balls, and normally holding no more than 300 people. In the middle of the century, halls designed specifically for concerts began to be built, such as The Holywell Music Room in Oxford, the Hanover Square Rooms in London, built in 1775, Concertsaal des Junghofes built in Frankfurt in 1756. In Berlin, the Concertsaal of the masonic lodge 'Royal York', built in 1803 , held 1000 people, and the hall of the Sing-Akademie, put up in 1826, could accommodate 1200. From the 1830s many concert halls were built and managed by piano manufacturers and music publishers, essentially for virtuoso and benefit concerts. The concert halls established after the middle of the 19th century displayed the lofty role that concerts had come to hold in European cultural life (Musikvereinsaal of the Gesellschaft der Musikfreunde in Vienna, Royal Albert Hall in London (1871), the Zürich Tonhalle (1891) and the Jahrhunderthalle in Breslau (1900)). The capacity of over 6000 at the Royal Albert Hall set a new scale in concert spaces. The classical 18th- and 19th-century repertory now stood as the core of musical taste, it demanding quiet and attentive listening (Weber 2001).

10 Tendencies to recreate antique Greek tragedy were not reserved solely for concert performances. Sacralization of the music life was even more obvious in opera in the second half of the $19^{\text {th }}$ century, one of the most explicit examples being Richard Wagner's project of Bayreuth Festival (Jeremić-Molnar 2007, 273 341). Also, there were similar tendencies in other arts. For instance, the institution of museum was just the same as the concert proclaimed to be the temple of arts that included strictly defined patterns of ritual behaviour (Duncan 1998, 473 497). 
was evident in representations of Greek and Roman gods on the concert halls' walls, though themes from pagan and Christian spirituality shaped decorations Kramer 2005, 146-147). Moreover, religious connotations were present in the official discourse of the critique. Commenting openings of the new buildings, their importance was regularly pointed out by critics' proclamation of those spaces as the temples of music. Pointing to personal sacrifices that were needed to be done by the listeners was also something regularly mentioned, especially regarding understanding certain works of art, such were Ludwig van Beethoven's symphonies (DeNora 1995). Further intensification of the applying of sacred ideals on the concert music was done due to the fact that church music was also performed in concerts (Kramer 2005, 159-161).

\section{Conclusion}

I presented in this paper some of the most salient components of the public concert that developed in $19^{\text {th }}$ century as an institution closely related to the idea of Kunstreligion developing in music aesthetics of the time. Rather that giving summary remarks, I will here briefly point to other relevant factors regarding the issue of music and religion, and, specifically, the role of concert in promoting certain aesthetical concepts about music as religion. Related to the reconstruction of the role of the concert in a certain life style is the issue of values propagated by certain concerts and the discourses on them. Mapping the phenomenon of concert life in the broader social context brings to the questions of the role of it in music culture. Thus, related phenomena are: the valuing of the music performed at a specific concert, making a hierarchy of genres, a hierarchy of performers (professionals/amateurs) and listeners (true Liebhaber/lay persons), and, finally, the influence of those standards on the concert life in the time to come, since the issue how intertwined religious atmosphere and cultivation project was in the period after 19th century has not yet been fully elaborated. It is relevant to have in mind how many $19^{\text {th }}$-century aesthetical concepts related to music and religion has been present ever since, being visible in the behavior patterns worldwide in the very same 'serious' music concerts. In other words, even today, we listen to 'serious' music in a concert hall as if we were in a church and it is just a continuation of the same concept of Kunstreligion that developed during the $19^{\text {th }}$ century.

\section{Bibliography}

Bourdieu, Pierre. 1979. La distinction: Critique sociale du jugement. Paris: Les Editions de Minuit.

Čejni, Dejvid. 2003. Životni stilovi. Beograd: Clio.

DeNora, Tia. 1991. "Musical Patronage and Social Change in Beethoven's Vienna". The American Journal of Sociology 97 (2): 310-346.

DeNora, Tia. 1995. Beethoven and the Construction of Genius. Musical Politics in Vienna, 1792-1803. Berkeley, Los Angeles and London: University of California Press. 
Duncan, Carol. 1998. "The Art Museum as Ritual”, in The Art of Art History. A Critical Anthology, edited by Donald Prezioni, 473-485. Oxford: Oxford University Press.

Ellis, Katharine. 2002. "The Structures of Musical Life", in The Cambridge History of Nineteeth-Century Music, edited by Jim Samson, 343-370. Cambridge: Cambridge University Press.

Gramit, David. 2002. Cultivating Music. The Aspirations, Interests and Limits of German Musical Culture, 1770-1848, Berkeley, Los Angeles and London: University of Calfornia Press.

Jeremić-Molnar, Dragana. 2007. Rihard Vagner: konstruktor "istinske" realnosti. Beograd: Fabrika knjiga.

Johnson, James H. 1995. Listening in Paris. A Cultural History, Berkeley, Los Angeles i London: University of California Press.

Kramer, Elisabeth A. 2005. The Idea of Kunstreligion in German Musical Aesthetics of The Early Nineteenth Century. University of North Carolina at Chapel Hill: dissertation for the degree of Doctor of Philosophy in the Department of Music.

Morrow, Mary Sue. 1997. German Music Criticism in the Late Eighteenth Century, Cambridge: Cambridge University Press.

Petrov, Ana. 2011. "Koncert kao građanska institucija”. Sociologija 53 (2): 177-194.

Pieper, Antje. 2008. Music and the Making of Middle-Class Culture. A Comparative History of Nineteenth-Century Leipzig and Birmingham, New York: Palgrave Macmillan.

Weber, William. 2001. "Concert", in Grove Music Online edited by L. Macy. (accessed on 20. 12. 2007), <http://www.grovemusic.com>

Weber, William. 2004. Music and The Middle Class. The Social Structure of Concert Life in London, Paris and Vienna between 1830 and 1848. London: Ashgate.

\section{POVZETEK}

Institucija javnega koncerta se je v prvi polovici 19. st. močno spremenila zaradi političnih, ekonomskih in demografskih sprememb. V najpomembnejših kulturnih središčih (London, Pariz in Dunaj) sta se močno povečala število in raznolikost koncertov. Koncertno življenje je odražalo tudi globoke družbene spremembe, ki so zajele vse plasti prebivalstva in so vplivale na način, kako so njihovi predstavniki izkoriščali svoj prosti čas. Z uporabo koncepta odlikovanja, ki ga je utemeljil Pierre Bourdieu, analiziram javni koncert kot obliko kulturnega delovanja, namenjeno ustvarjanju in utrjevanju novega statusa meščanstva in njengovega kulturnega etosa. Ker so se koncerti odvijali na različnih prizoriščih (koncertne dvorane, kavarne, restavracije, parki, saloni ali plesne dvorane), so ponujali različne oblike razvedrila. Upoštevam tudi razlike med koncerti in razpravljam na eni strani o razmerjih med njimi, na drugi pa o konceptu "umetnosti" in "razvedrila", pri čemer se osredotočam na poti, pa katerih je bil uresničen koncept Kunstreligion. Javni koncert je pomagal vzpostaviti razlikovanje med "visokim" in "nizkim" razvedrilom ter s tem tudi ločnico med "intelektualnim" in "neukim" občinstvom. Ločnica je nastala $\mathrm{v}$ diskurzu o glasbi in v mikrosocialnih položajih na koncertih, $v$ družbeni stvarnosti pa je postala vidna glede na to, kakšne vrste koncerta se je poslušalec udeležil, kako se je na koncertu obnašal in kako je poslušal glasbo. Koncept Kunstreligion je bil povezan s koncerti $\mathrm{v}$ koncertnih dvoranah (te so bile pogosto zasnovane tako, da so bile podobne svetiščem), namenjenimi izobraženemu občinstvu. Ti niso bili razumljeni kot razvedrilo, temveč prej kot (umetniško, glasbeno) nadomestilo za cerkveno obredje (Gottesdienst), ter so tako znova vzpostavljali razlikovanje med "duhovno" in "profano" glasbo. Skladne z"estetsko kontemplacijo", ki so jo razširjali filozofski diskurzi in tisk 19. stoletja, so bile zahteve po tem, da se obiskovalci obnašajo, "kot bi bili v cerkvi”. Priporočila za" primerno" vedenje so obsegala: bodi pri miru, bodi tiho in spoštljiv, ne premikaj se, osredotoči se na opazovanje in premišljanje o glasbi. Tako so bili koncerti pridržani občinstvi, ki je bilo dovolj "kultivirano", da je "pobožno" poslušalo glasbo.

Prevod naslova, izvlečka in povzetka Aleš Nagode. 